\title{
Ambient and indoor particulate aerosols generated by dairies in the southern High Plains ${ }^{1}$
}

\author{
C. W. Purdy, ${ }^{*}$ R. N. Clark, ${ }^{*}$ and D. C. Straus $\dagger^{2}$ \\ *USDA, Agricultural Research Service, Conservation and Production Research Laboratory, PO Drawer 10, Bushland, TX 79012 \\ †Department of Microbiology and Immunology, Texas Tech University Health Sciences Center, Lubbock 79430
}

\begin{abstract}
The objectives were to quantify and size ambient aerosolized dust in and around the facilities of 4 southern High Plains dairies of New Mexico and to determine where health of workers might be vulnerable to particulate aerosols, based on aerosol concentrations that exceed national air quality standards. Ambient dust air samples were collected upwind (background) and downwind of 3 dairy location sites (loafing pen boundary, commodity, and compost field). The indoor milking parlor, a fourth site, was monitored immediately upwind and downwind. Aerosolized particulate samples were collected using high-volume sequential reference air samplers, laser aerosol monitors, and cyclone air samplers. The overall (main effects and estimable interactions) statistical general linear model statement for particulate matter $\left(\mathrm{PM}_{10}\right.$; particulate matter with an aerodynamic diameter of up to $10 \mu \mathrm{m}$ ) and $\mathrm{PM}_{2.5}$ resulted in a greater mean concentration of dust in the winter $\left(\mathrm{PM}_{10}=97.4 \pm 4.4 \mu \mathrm{g} / \mathrm{m}^{3} ; \mathrm{PM}_{2.5}=32.6 \pm 2.6\right.$ $\left.\mu \mathrm{g} / \mathrm{m}^{3}\right)$ compared with the summer $\left(\mathrm{PM}_{10}=71.9 \pm 5.0\right.$ $\left.\mu \mathrm{g} / \mathrm{m}^{3} ; \mathrm{PM}_{2.5}=18.1 \pm 1.2 \mu \mathrm{g} / \mathrm{m}^{3}\right)$. The upwind and downwind boundary $\mathrm{PM}_{10}$ concentrations were significantly higher in the winter (upwind $=64.3 \pm 9.5 \mu \mathrm{g}$ / $\mathrm{m}^{3}$; downwind $\left.=119.8 \pm 13.0 \mu \mathrm{g} / \mathrm{m}^{3}\right)$ compared with the summer (upwind $=35.2 \pm 7.5 \mu \mathrm{g} / \mathrm{m}^{3}$; downwind $\left.=66.8 \pm 11.8 \mu \mathrm{g} / \mathrm{m}^{3}\right)$. The milking parlor $\mathrm{PM}_{10}$ and $\mathrm{PM}_{2.5}$ concentration data were significantly higher in the winter $\left(\mathrm{PM}_{10}=119.5 \pm 5.8 \mu \mathrm{g} / \mathrm{m}^{3} ; \mathrm{PM}_{2.5}=55.3 \pm\right.$ $\left.5.8 \mu \mathrm{g} / \mathrm{m}^{3}\right)$ compared with the summer $\left(\mathrm{PM}_{10}=88.6 .0\right.$ $\left.\pm 5.8 \mu \mathrm{g} / \mathrm{m}^{3} ; \mathrm{PM}_{2.5}=21.0 \pm 2.1 \mu \mathrm{g} / \mathrm{m}^{3}\right)$. Personnel should be protected from high aerosol concentrations found at the commodity barn, compost field, and milking parlor during the winter.
\end{abstract}

\footnotetext{
Received June 18, 2009.

Accepted September 16, 2009.

${ }^{1}$ Mention of trade names or commercial products in this article is solely for the purpose of providing specific information and does not imply recommendation or endorsement by the U.S. Department of Agriculture.

${ }^{2}$ Corresponding author: David.Straus@ttuhsc.edu
}

Key words: dairy aerosolized dust, particulate size, disease potential

\section{INTRODUCTION}

Air quality has been an important public concern (Seinfeld, 2004) especially with the increase in haze seen on the horizon (e.g., Columbia River Gorge, OR) compared with past years. This haze results from an increase in fine particular matter (PM) pollution (Green and $\mathrm{Xu}, 2007)$. Industrial air pollution composed of PM and toxic gases in large metropolitan areas results in crises for human health when certain meteorological conditions keep the pollution from dissipating. These events have produced a high incidence of respiratory morbidity and mortality (Logan, 1953).

A high incidence of cardiac morbidity and mortality occurred during severe air pollution events (Samet et al., 2000). These events brought about new laws and standards, starting with the Clean Air Act of 1963, which authorized the US Environmental Protection Agency (EPA) to issue a set of national ambient air quality standards (NAAQS). These critical standards were designed for particulate matter, sulfur dioxide, ozone, nitrogen oxides, and lead. The standard developed in 1987 for ambient aerosol particles in the size range of 10 $\mu \mathrm{m}$ diameter $\left(\mathbf{P M}_{\mathbf{1 0}}\right)$ was to not exceed $150 \mu \mathrm{g} / \mathrm{m}^{3}$ per $24 \mathrm{~h}$ or the average of $50 \mu \mathrm{g} / \mathrm{m}^{3}$ per yr (Cleland, 1998). On September 21, 2006, the EPA lowered the NAAQS standard for fine particulate pollutant concentration in the size range of $2.5 \mu \mathrm{m}$ diameter $\left(\mathbf{P M}_{2.5}\right)$ to $35 \mu \mathrm{g} /$ $\mathrm{m}^{3}$ per $24 \mathrm{~h}$ or $15 \mathrm{\mu g} / \mathrm{m}^{3}$ per yr (http://epa.gov/pm/ naaqsrev2006.html).

These standards were designed for urban air pollution, which is created mainly by the exhaust of combustion engines, the emission of burning wood and coal, and from heavy manufacturing industries. Rural (agricultural) aerosol pollution (Centner, 2001) was thought to affect fewer people than urban pollution. Yet, the rural United States includes vast areas of the country that have different climates, soil types, topographies, and farm (ranch) management practices. Few publications exist on aerosol pollution that covers the many 
agriculture enterprises and there is a need to monitor particulate exposure in rural areas where there is a gap in our knowledge. Concentrated animal feeding operations (CAFO) in the chicken, hog, feeder calf, and dairy industries have come under increased scrutiny for both water and air pollution caused by the collection and disposal of enormous amounts of animal waste (Centner, 2003). Concerns for the health of workers and animals in these industries and downwind neighbors of these industries were expressed because of dust aerosols (Purdy et al., 2002a,b), odors (Kirkhorn, 2002), and water pollution (Purdy et al., 2001, 2004a). With these concerns, few studies have measured particulate dust downwind of CAFO.

This study was designed to measure aerosol particles generated by large dairies located in the southern High Plains of New Mexico and to determine operation sites where health of workers might be negatively affected by particulate aerosols, based on aerosol concentrations that exceed NAAQS thresholds. Our hypothesis was that dairy $\mathrm{PM}_{10}$ and $\mathrm{PM}_{2.5}$ ambient aerosols would occasionally exceed NAAQS thresholds.

The objectives were to 1 ) determine the concentration $\left(\mu \mathrm{g} / \mathrm{m}^{3}\right)$ of $\mathrm{PM}_{2.5}$ and $\mathrm{PM}_{10}$ aerosol particles collected sites at each of 4 locations; 2) determine the concentration of background particulates; 3) determine the amount of $\mathrm{PM}_{2.5}$ and $\mathrm{PM}_{10}$ emissions from each dairy; 4) determine if each dairy was compliant with the EPA particulate standards for each 24-h period monitored; and 5) investigate potential aerosol sources that may negatively affect human health and suggest solutions.

\section{MATERIALS AND METHODS}

\section{Experimental Design}

Particulate aerosols were collected upwind and downwind of loafing pen boundaries, commodity barns where feed was mixed daily, and compost fields where the manure was processed on 4 large dairies. Indoor aerosols in the milking parlor were also investigated. Each dairy was examined for aerosol concentrations for approximately $28 \mathrm{~d}$ in both the summer and winter of 2006 and 2007.

Air particulate collection equipment was placed on the upwind and downwind boundaries of the dairy loafing yards. The average distance between the upwind and downwind air monitors was $686 \pm 20 \mathrm{~m}$. The prevailing winds in the summer were flowing out of the southwest toward the northeast, and during the winter from the northeast toward the southwest. Summer was defined as April through September and winter was defined as October through March. Replicate air monitors in the upwind and downwind positions were placed $6 \mathrm{~m}$ apart and were $3 \mathrm{~m}$ from the boundary fences that contained the cows in the loafing pens. Air monitors were placed upwind and downwind at the commodity barns (approximately $122 \mathrm{~m}$ between positions and $15 \mathrm{~m}$ from the barn) and the monitors were similarly placed in the compost fields (approximately $323 \mathrm{~m}$ between positions and $15 \mathrm{~m}$ from the compost fields). The gravimetric aerosol concentrations were averaged between the 2 positions at the commodity barns and compost fields (averaged for all 4 dairies), because 24-h samples were collected and the wind frequently changed from upwind to downwind directions over a $24-\mathrm{h}$ period. The commodity buildings and bins created a great deal of mixing of the air. Although the laser monitors were similarly located with the gravimetric monitors, laser monitors collected aerosols on an hourly basis, and upwind and downwind samples could be sorted into upwind or downwind data pools according to the hourly weather station data. Air monitors were placed $6 \mathrm{~m}$ apart upwind and downwind at the boundaries, commodity barn, and compost field. Electricity was supplied by $5.5 \mathrm{~kW}$ diesel generators (model 11688, Hardy Diesel, Jamul, CA).

\section{Sample Populations and Dairy Description}

Four commercial dairies (D3, 4,000 cows; D4, 6,000 cows; D5, 7,100 cows; and D6, 2,400 cows) were used. Cows on all dairies were milked 3 times daily. Each dairy had similar milking parlors with a holding area behind the milking parlors that contained the cows waiting to be milked. All milking parlors had a central working alley for milking personnel and equipment. Each dairy cow was trained to back into the milking stanchions, after which barrier bars were lowered to prevent forward movement.

The barns were open on the end next to the waiting cows holding pen; passive ventilators were located on the hip of the roof and under the eaves (between roof and the outer walls), and louvered windows were located in the outer walls. Stationary electric fans (circular, 61 $\mathrm{cm}$ in diameter) were mounted above the center alley and drew air from the open end of the barn, louvered windows, and from under the eaves into the milking parlors; air exited the open doors in the middle of the building at the front of the milking parlors during the hot months. During the winter, the doors and louvered windows were closed and the fans were turned off. Natural gas heaters were located above the center of the work alley and they provided some heat for the workers during the winter. All floor surfaces were flushed with water after each set of cows was milked.

After milking, the cows were moved to a concrete feeding alley approximately $7 \mathrm{~m}$ wide and $541 \mathrm{~m}$ long where they ate through stanchions. After eating, the 
cows were moved to loafing pens approximately 20.3 ha in size. These pens were equipped with multiple sunshades approximately $7 \mathrm{~m}$ wide and $190 \mathrm{~m}$ long, located in the middle of the pens. Each dairy mixed and prepared their feed rations in their own commodity barn. Three of the 4 dairies had facilities for composting manure in windrows at a distant site. The dairies were all within a $30-\mathrm{km}$-diameter circle in the southern High Plains of New Mexico.

\section{Air Monitoring Instruments}

Aerosolized particulates in the loafing yard were analyzed by use of high-volume $\left(1 \mathrm{~m}^{3} / \mathrm{h}\right)$ sequential reference ambient air samplers (RAAS; 300 series, Andersen Instruments, Smyrna, GA). The $\mathrm{PM}_{10}$ (Code of Federal Regulations, 1997a) and $\mathrm{PM}_{2.5}$ (Code of Federal Regulations, 1997b) monitors (2 each; RAAS 300 series) were standalone sampling systems that met the federal reference method (FRM). The air intake orifice for the RAAS instruments was $1.9 \mathrm{~m}$. Each filter (Whatman Filter Device, $2-\mu \mathrm{m}$ polytetrafluoroethylene, $46.2 \mathrm{~mm}$, Cole Palmer, Vernon Hills, IL) was identified and its weight (accurate to $10 \mu \mathrm{g}$ ) recorded after $33 \%$ relative humidity equilibration. This was done before use and again after collection of ambient particulates. The $\mathrm{PM}_{2.5}$ WINS impactor (provided a 2.5- $\mu \mathrm{m}$ threshold point) glass fiber filter (Whatman 934-AH $37 \mathrm{~mm}$, Cole Palmer) was prepared with 1 drop of supplied oil, which was replaced every $3 \mathrm{~d}$ when the instrument was cleaned. The RAAS airflow rate was maintained at $16.6 \mathrm{~L} / \mathrm{min}$ and the instrument was recalibrated (RAAS operator's manual, section 8, 8-1-8-45, Andersen Instruments) every 3 mo. A new term, inhalable coarse particulates $\left(\mathbf{P M}_{\mathbf{I C}}\right)$, recently introduced by the EPA (Environmental Protection Agency, 2006), was calculated by subtracting the $\mathrm{PM}_{2.5}$ fraction from the $\mathrm{PM}_{10}$ fraction.

Two $\mathrm{PM}_{10}$ DustTrak aerosol laser monitors (model 8520, TSI Inc., Shoreview, MN) were similarly situated in the same locations and positions as the Andersen RAAS-300 samplers. Each laser monitor was encased in an environmental enclosure that was mounted onto a surveyor's aluminum tripod (CST/Berger, Watseka, IL) at a height of $1 \mathrm{~m}$. These monitors used a directreading, real-time, light-scattering laser photometer. The laser light emitted from the diode was scattered by particles drawn through the unit in a constant stream, and the amount of light scatter determined the particle mass concentration (Liu et al., 2002). The flow rate was set by the factory at $1.7 \mathrm{~L} / \mathrm{min}$, and the monitors were maintained at that flow rate by using the flow meter supplied with the monitor; data were recorded every hour for $8 \mathrm{~d}$ at each position. The instruments were maintained and recalibrated in the field by cleaning every $3 \mathrm{~d}$, emptying water traps, and re-zeroing by using the zero filter and keyboard. Internal high-efficiency particulate air (HEPA) filters were changed every 700 $\mathrm{h}$ or as prompted by the software. The instruments were returned annually to the factory for servicing. The DustTrak instruments had one advantage over the RAAS monitors in that they determined hourly $\mathrm{PM}_{10}$ mean concentrations.

\section{Cyclone Air Sampler}

Two cyclone air samplers (In-Tox Products, Albuquerque, NM) were made of brass piping with slip joints and specially designed chambers that collected particulates based on their aerodynamic diameters (5.2 to $1 \mu \mathrm{m}$ ) into 5 chambers, and finally the smallest particles $(0.32 \mu \mathrm{m}$ diameter $)$ were collected onto a filter. These air samplers were used in the upwind and downwind boundaries, commodity barns, and compost fields. Vacuum pumps (model 1531-320-G557X, Gast Mfg., Benton Harbor, MI) attached to the cyclone devices were calibrated to maintain a flow rate of $28.4 \mathrm{~L} /$ min for $24 \mathrm{~h}$. The cyclone intake orifice height was $1 \mathrm{~m}$. After collection of dust particles, the device was disassembled and the particulates weighed on an analytical balance as described above (Materials and Methods, Air Monitoring Instruments).

\section{Weather Station}

Weather conditions were monitored for each dairy by use of a portable weather station (model Met Data1, Campbell Scientific, Logan, UT) equipped with a 3.5-m tower. The weather station measured and recorded wind speed, wind direction, relative humidity, precipitation, air temperature, solar radiation, barometric pressure, and time. The sampling time occurred at 30-s intervals and the recording times were 15 -min, 1 -h, and 24-h intervals.

\section{Statistical Analysis}

The experiment was conducted as a completely randomized design with air sample as the experimental unit. Data were analyzed with ANOVA by use of a general linear model procedure (SAS Institute, 1988). The model included 4 dairies, 2 seasons (summer and winter), 4 location sites (boundaries, commodity barns, compost fields, and milking parlors), as well as upwind and downwind or front and back for milking parlors. A 2-way ANOVA was used to examine the interactions between dairy and season, location site and season, location site, and dairy on the $2.5-\mu \mathrm{m}$ respirable par- 
ticle and the $10-\mu \mathrm{m}$ nonrespirable particle populations. Significant differences between groups were further evaluated by use of the Bonferroni and Duncan adjusted paired $t$-test. Differences were considered significant at $P \leq 0.05$. Standard error of the mean $( \pm \mathrm{SEM})$ was used throughout. The Proc Correlation procedure was used to analyze correlations between RAAS $\mathrm{PM}_{10}$ and $\mathrm{PM}_{2.5}$ (and DustTrak $\mathrm{PM}_{10}$ ) ambient air collections $\left(\mu \mathrm{g} / \mathrm{m}^{3}\right)$ and the weather components [relative humidity $(\%)$, wind speed $(\mathrm{m} / \mathrm{s})$, wind direction, solar radiation $\left(\mathrm{W} / \mathrm{m}^{2}\right)$, and barometric pressure $\left.(\mathrm{mmHg})\right]$. The Proc Correlation analysis was reported as Pearson correlation coefficients. The significance of Pearson correlations was evaluated using the 2-tailed $F$-statistics, which provided the test of the null hypothesis that $\mathrm{r}$ (or $\left.\mathrm{R}^{2}\right)=$ zero $(\operatorname{Pr}<F)$. Dust concentration emission factor was calculated by pairing simultaneous downwind and upwind values. From each paired value, the mean upwind concentration was subtracted from the mean downwind concentration.

\section{RESULTS}

\section{Comparison of RAAS-300 FRM Sequential $P M_{10}$ and $P_{2} M_{2.5}$ Particulate Data}

The overall ANOVA combining $\mathrm{PM}_{10}$ and $\mathrm{PM}_{2.5}$ aerosol particulates $\left(\mu \mathrm{g} / \mathrm{m}^{3}\right)$ for all dairies both upwind and downwind determined that a difference $(P<0.0001)$ occurred among particle size concentration $\left(\mathrm{PM}_{2.5}, 23.5\right.$ $\pm 1.3 \mu \mathrm{g} / \mathrm{m}^{3} ; \mathrm{PM}_{\mathrm{IC}}, 72.1 \pm 4.5 \mu \mathrm{g} / \mathrm{m}^{3}$; and $\mathrm{PM}_{10}, 84.6$ $\left.\pm 4.3 \mu \mathrm{g} / \mathrm{m}^{3}\right)$; and the winter aerosol concentration was more concentrated $\left(65.9 \pm 2.7 \mu \mathrm{g} / \mathrm{m}^{3}\right)$ compared with the summer $\left(56.2 \pm 3.4 \mu \mathrm{g} / \mathrm{m}^{3} ; P<0.0388\right)$. Overall, D3 $\left(49.8 \pm 2.5 \mu \mathrm{g} / \mathrm{m}^{3}\right)$ and D6 $\left(51.8 \pm 3.1 \mu \mathrm{g} / \mathrm{m}^{3}\right)$ had lower concentrations of aerosol particles $\left(\mathrm{PM}_{2.5}\right.$ and $\mathrm{PM}_{10}$ combined) than D4 $\left(70.1 \pm 5.1 \mu \mathrm{g} / \mathrm{m}^{3}\right)$ and D5 $\left(67.0 \pm 5.4 \mu \mathrm{g} / \mathrm{m}^{3} ; P<0.0001\right)$.

\section{Analysis of RAAS-300 FRM Sequential $P M_{10}$ Particulate Data}

The compost fields were not present on all our dairies; therefore, data from the dairies without compost fields were removed from the following statistics. The overall RAAS $\mathrm{PM}_{10}$ mean concentrations were less $\left(71.9 \pm 5.8 \mu \mathrm{g} / \mathrm{m}^{3}\right)$ in the summer compared with the winter $\left(97.9 \pm 4.4 \mu \mathrm{g} / \mathrm{m}^{3} ; P<0.0001\right)$. There were differences among the dairies' aerosol concentrations $(P<0.0005)$. Dairy 4 had a higher $(104.9 \pm 10.9 \mu \mathrm{g} /$ $\left.\mathrm{m}^{3}\right) \mathrm{PM}_{10}$ concentration compared with the others (D3, $70.1 \pm 4.8 \mu \mathrm{g} / \mathrm{m}^{3} ; \mathrm{D} 6,76.7 \pm 6.9 \mu \mathrm{g} / \mathrm{m}^{3}$; and D5, 82.7 $\left.\pm 5.5 \mu \mathrm{g} / \mathrm{m}^{3} ; P<0.05\right)$. The dairy upwind boundary concentration (all sites pooled) was less $(48.1 \pm 6.2$ $\mu \mathrm{g} / \mathrm{m}^{3}$ ) compared with the downwind boundary (90.7 $\left.\pm 9.2 \mu \mathrm{g} / \mathrm{m}^{3} ; P<0.0001\right)$. The wind currents at the commodity barns mixed the air because of the building structures; therefore, only a RAAS $\mathrm{PM}_{10}$ mean concentration of the upwind and downwind combined was reported $\left(81.0 \pm 8.5 \mu \mathrm{g} / \mathrm{m}^{3}\right)$. The front of the milking parlor had a RAAS $\mathrm{PM}_{10}$ concentration of $91.0 \pm 6.0$ $\mu \mathrm{g} / \mathrm{m}^{3}$, and the back of the milking parlor had a RAAS $\mathrm{PM}_{10}$ concentration of $112.2 \pm 7.3 \mu \mathrm{g} / \mathrm{m}^{3}(P>0.05)$.

\section{Analysis of RAAS PM 10 Mean Concentrations Among Dairies}

The upwind boundary $\mathrm{PM}_{10}$ mean concentration was higher $\left(64.3 \pm 9.5 \mu \mathrm{g} / \mathrm{m}^{3}\right)$ in the winter compared with the summer $(35.2 \pm 7.5)$, and the pattern was the same for the winter downwind $(119.80 \pm 13.0)$ compared with the summer downwind $\left(66.8 \pm 11.8 \mu \mathrm{g} / \mathrm{m}^{3} ; P<\right.$ 0.0148). The $\mathrm{PM}_{10}$ concentration of the commodity barn was not different between the seasons (winter, $81.0 \pm 7.3$ vs. summer, $\left.80.9 \pm 15.1 \mu \mathrm{g} / \mathrm{m}^{3}\right)$. The milking parlors, both front $\left(107.1 \pm 11.8 \mu \mathrm{g} / \mathrm{m}^{3}\right)$ and back $\left(132.4 \pm 11.8 \mu \mathrm{g} / \mathrm{m}^{3}\right)$, were significantly higher in the winter compared with the summer (front, $75.4 \pm 11.8$ $\mu \mathrm{g} / \mathrm{m}^{3}$; back, $\left.96.2 \pm 10.0 \mu \mathrm{g} / \mathrm{m}^{3} ; P<0.0200\right)$.

The RAAS $\mathrm{PM}_{10}$ upwind and downwind mean concentrations were not different among the dairies. The mean concentration of the D4 commodity barn was higher $\left(151.9 \pm 29.7 \mu \mathrm{g} / \mathrm{m}^{3}\right)$ than D3 $(49.4 \pm 5.0 \mu \mathrm{g} /$ $\left.\mathrm{m}^{3}\right), \mathrm{D} 5\left(67.7 \pm 7.4 \mu \mathrm{g} / \mathrm{m}^{3}\right)$, and D6 $(56.9 \pm 29.7 \mu \mathrm{g} /$ $\left.\mathrm{m}^{3} ; P<0.05\right)$. Dairy 3 had a lower $\mathrm{PM}_{10}$ concentration in the front of the milking parlor $(52.6 \pm 13.3 \mu \mathrm{g} /$ $\left.\mathrm{m}^{3}\right)$ and in the back of the milking parlor $(83.2 \pm 13.3$ $\mu \mathrm{g} / \mathrm{m}^{3}$ ) compared with D4 (front, $103.5 \pm 13.3 \mu \mathrm{g} / \mathrm{m}^{3}$; back, $168.1 \pm 16.4 \mu \mathrm{g} / \mathrm{m}^{3}$ ), D5 (front, $119.9 \pm 13.3 \mu \mathrm{g}$ / $\mathrm{m}^{3}$; back, $119.5 \pm 11.8 \mu \mathrm{g} / \mathrm{m}^{3}$ ), and D6 (front, $90.4 \pm$ $\left.9.0 \mu \mathrm{g} / \mathrm{m}^{3} ; 91.3 \pm 1.5 \mu \mathrm{g} / \mathrm{m}^{3} ; P<0.0001\right)$.

\section{Analysis of Mean, Maximum, and Minimum RAAS PM 10 and $P_{M} M_{I C}$ Concentrations}

The RAAS $\mathrm{PM}_{10}$ maximum and minimum concentrations for upwind boundary, downwind boundary, commodity barns, milking parlor front and back, and compost fields were compared in the summer and winter (Table 1). The RAAS $\mathrm{PM}_{10}$ and $\mathrm{PM}_{\mathrm{IC}}$ daily concentrations that exceeded the NAAQS standard of $150 \mu \mathrm{g} /$ $\mathrm{m}^{3}$ per $24 \mathrm{~h}$ were determined upwind and downwind of each dairy location site (boundary, commodity barn, and compost field) in the summer and winter (Figure 1). The mean $\mathrm{PM}_{10}$ and $\mathrm{PM}_{\mathrm{IC}}$ concentrations were determined for inside the milking parlor (Figure 1). There is no recognized standard for indoor air. 
Table 1. Reference ambient air samplers 24-h $\mathrm{PM}_{10}$ (particulate matter with an aerodynamic diameter of up to $10 \mu \mathrm{m}$ ) aerosol concentrations (mean \pm SEM, minimum, and maximum $\mu \mathrm{g} / \mathrm{m}^{3}$ ) in summer and winter for 4 dairy upwind boundaries, downwind boundaries, commodity barns, compost fields, and milking parlors front and back

\begin{tabular}{|c|c|c|c|c|c|c|c|}
\hline Season & Position & Replications & Probability & Mean & SEM & Minimum & Maximum \\
\hline Winter & Upwind winter & 31 & 0.0148 & 64.3 & 9.5 & 0.8 & 180.4 \\
\hline Summer & Downwind summer & 39 & 0.0034 & 66.8 & 11.8 & 6.7 & 433.8 \\
\hline Summer & Commodity barn & 63 & 0.8896 & 80.9 & 15.1 & 5.0 & 781.0 \\
\hline Winter & Commodity barn & 60 & 0.8896 & 81.0 & 7.3 & 13.7 & 275.6 \\
\hline Summer & Compost field & 43 & 0.0645 & 108.2 & 26.1 & 4.2 & 914.8 \\
\hline Winter & Milking parlor front & 32 & 0.0003 & 107.1 & 5.7 & 20.4 & 173.9 \\
\hline Winter & Milking parlor back & 31 & 0.0200 & 132.4 & 9.8 & 44.9 & 282.5 \\
\hline
\end{tabular}

The $\mathrm{PM}_{\mathrm{IC}}$ concentration was not different between seasons or among location sites; however, it was higher $\left(90.2 \pm 10.5 \mu \mathrm{g} / \mathrm{m}^{3}\right)$ for $\mathrm{D} 4$ compared with the other dairies (D5, $78.7 \pm 11.8 \mu \mathrm{g} / \mathrm{m}^{3}$; D3, $57.8 \pm 3.8 \mu \mathrm{g} / \mathrm{m}^{3}$; and D6, $\left.57.3 \pm 6.0 \mu \mathrm{g} / \mathrm{m}^{3} ; P<0.05\right)$. The RAAS mean $\mathrm{PM}_{10}$ daily concentrations that exceeded the NAAQS standard of $150 \mu \mathrm{g} / \mathrm{m}^{3}$ per $24 \mathrm{~h}$ were determined by dairy (Figure 2).

\section{Analysis of RAAS $P_{2.5}$ Mean Concentrations by Seasons, Locations, and Dairies}

The $\mathrm{PM}_{2.5}$ winter aerosol concentration was higher $\left(32.6 \pm 2.6 \mu \mathrm{g} / \mathrm{m}^{3}\right)$ than the summer $(18.1 \pm 1.2 \mu \mathrm{g} /$ $\left.\mathrm{m}^{3}\right)$ concentration $(P<0.0001)$. There were no differences in $\mathrm{PM}_{2.5}$ mean concentrations among the upwind boundaries $\left(19.3 \pm 2.7 \mu \mathrm{g} / \mathrm{m}^{3}\right)$, downwind boundaries $\left(17.9 \pm 2.0 \mu \mathrm{g} / \mathrm{m}^{3}\right)$, and commodity barns $(16.9 \pm 1.2$ $\left.\mu \mathrm{g} / \mathrm{m}^{3} ; P<0.05\right)$. The milking parlor mean $\mathrm{PM}_{2.5}$ concentrations were higher than the upwind, downwind, and commodity barn concentrations $(P<0.05)$. The mean concentration in front of the milking parlors was higher $\left(44.8 \pm 6.4 \mu \mathrm{g} / \mathrm{m}^{3}\right)$ than that in the back of the milking parlors $\left(35.2 \pm 3.6 \mu \mathrm{g} / \mathrm{m}^{3} ; P<0.05\right)$. The $\mathrm{PM}_{2.5}$ mean aerosol concentrations were significantly $(P<0.0001)$ different among the dairies. The mean aerosol concentration of D3 was less $\left(17.5 \pm 0.9 \mu \mathrm{g} / \mathrm{m}^{3}\right)$ than that of D5 $\left(36.2 \pm 4.9 \mu \mathrm{g} / \mathrm{m}^{3}\right)$ and D6 $(26.5 \pm 2.5$ $\left.\mu \mathrm{g} / \mathrm{m}^{3}\right)$; that of D4 was intermediate $(20.6 \pm 2.5 \mu \mathrm{g} /$ $\left.\mathrm{m}^{3} ; P<0.05\right)$ and between that of D3 and D5.

There were no significant differences in mean $\mathrm{PM}_{2.5}$ concentrations in the winter or summer for upwind boundary or downwind boundary data. There was a higher $\mathrm{PM}_{2.5}$ mean aerosol concentration for the commodity barn $\left(21.9 \pm 2.0 \mu \mathrm{g} / \mathrm{m}^{3}\right)$, milking parlor front $\left(63.1 \pm 9.8 \mu \mathrm{g} / \mathrm{m}^{3}\right)$, and milking parlor back $(47.6 \pm$ $\left.6.3 \mu \mathrm{g} / \mathrm{m}^{3} ; P<0.002\right)$ in the winter compared with the summer $\left(24.2 \pm 2.7 \mu \mathrm{g} / \mathrm{m}^{3} ; P<0.001\right)$.

\section{Analysis of $P M_{2.5}$ Mean Concentrations Among Dairies with Interactions}

The $\mathrm{PM}_{2.5}$ aerosol concentration of the upwind boundary data was higher $\left(33.4 \pm 9.1 \mu \mathrm{g} / \mathrm{m}^{3}\right)$ for D6 compared with the other dairies $(P<0.0006)$. The downwind boundary and commodity barn $\mathrm{PM}_{2.5}$ mean concentration was not significantly different among any of the dairies. The $\mathrm{PM}_{2.5}$ mean concentration was less $\left(14.3 \pm 0.04 \mu \mathrm{g} / \mathrm{m}^{3}\right)$ in the back of milking parlor D3 compared with that in D4 $\left(34.7 \pm 3.0 \mu \mathrm{g} / \mathrm{m}^{3}\right)$, D5 $(63.9$ $\left.\pm 9.9 \mu \mathrm{g} / \mathrm{m}^{3}\right)$, and D6 $\left(33.1 \pm 6.2 \mu \mathrm{g} / \mathrm{m}^{3} ; P<0.0001\right)$. The $\mathrm{PM}_{2.5}$ mean concentration was greater in the front of milking parlor in D5 $\left(91.7 \pm 6.2 \mu \mathrm{g} / \mathrm{m}^{3}\right)$ and D6 $\left(31.9 \pm 4.4 \mu \mathrm{g} / \mathrm{m}^{3}\right)$ compared with D3 $(26.4 \pm 4.4 \mu \mathrm{g} /$ $\mathrm{m}^{3}$ ) and D4 $\left(18.5 \pm 4.4 \mu \mathrm{g} / \mathrm{m}^{3} ; P<0.0001\right)$. Significant $\mathrm{PM}_{2.5}$ interactions occurred among the dairies (site $\times$ season $\times$ dairy; $P<0.0001$ ), indicating that unique influences affect individual dairies differently.

\section{Analysis of RAAS $P M_{2.5}$ Dairy Emissions}

The model statement for the RAAS $\mathrm{PM}_{2.5}$ emission concentration was significant $(P<0.0001)$, and the concentration was higher in summer $(15.2 \pm 3.6 \mu \mathrm{g} /$ $\left.\mathrm{m}^{3}\right)$ than in winter $\left(9.2 \pm 1.9 \mu \mathrm{g} / \mathrm{m}^{3} ; P<0.05\right)$. Dairy 6 had a higher emission concentration $(26.3 \pm 6.7 \mu \mathrm{g} /$ $\mathrm{m}^{3}$ ) compared with the other dairies in ascending order: $\mathrm{D} 5,3.9 \pm 0.7 \mu \mathrm{g} / \mathrm{m}^{3} ; \mathrm{D} 3,7.1 \pm 1.6 \mu \mathrm{g} / \mathrm{m}^{3}$; and D4, 12.6 $\pm 3.1 \mu \mathrm{g} / \mathrm{m}^{3}(P<0.05)$. The model statements for the dairy RAAS $\mathrm{PM}_{10}$ and $\mathrm{PM}_{\mathrm{IC}}$ emission concentrations were not significant.

\section{Analysis of Mean, Maximum, and Minimum RAAS PM ${ }_{2.5}$ and $P M_{I C}$ Concentrations}

The RAAS $\mathrm{PM}_{2.5}$ mean, minimum, and maximum concentrations for upwind boundary, downwind boundary, commodity barns, compost fields, and milking 

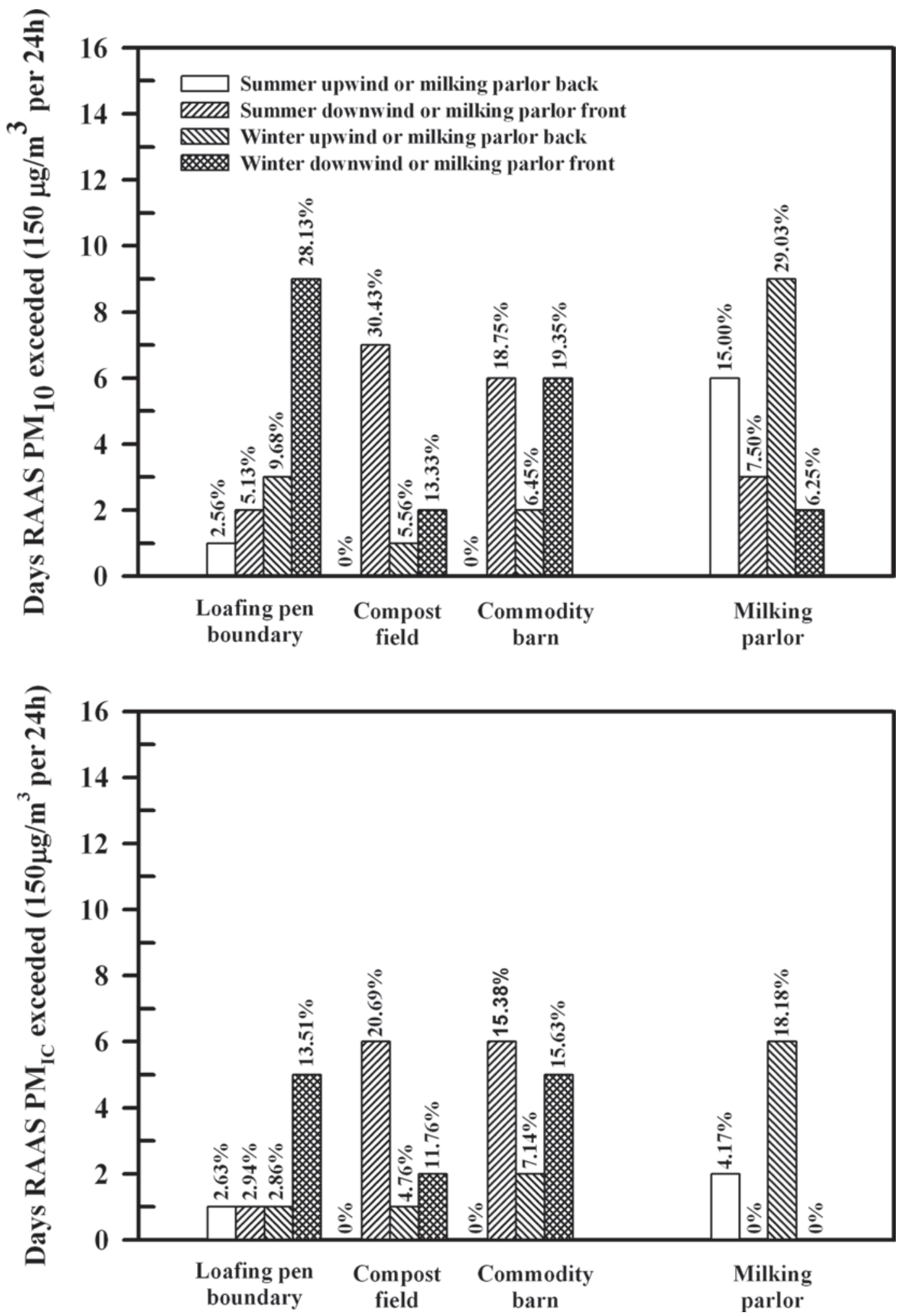

Figure 1. The number of days that reference ambient air samplers (RAAS, 300 series, Andersen Instruments, Smyrna, GA) particulate matter in the size range of $10 \mu \mathrm{m}\left(\mathrm{PM}_{10}\right)$ in diameter and inhalable coarse particulates $\left(\mathrm{PM}_{\mathrm{IC}}\right)$ concentrations exceeded the Environmental Protection Agency's standard $\left(150 \mu \mathrm{g} / \mathrm{m}^{3}\right.$ per $\left.24 \mathrm{~h}\right)$ by dairy location sites, upwind and downwind in the summer and winter; includes the milking parlor for which there is no standard for indoor air. The figure above each bar represents the percentage time out of compliance (days out of compliance/total days monitored). 

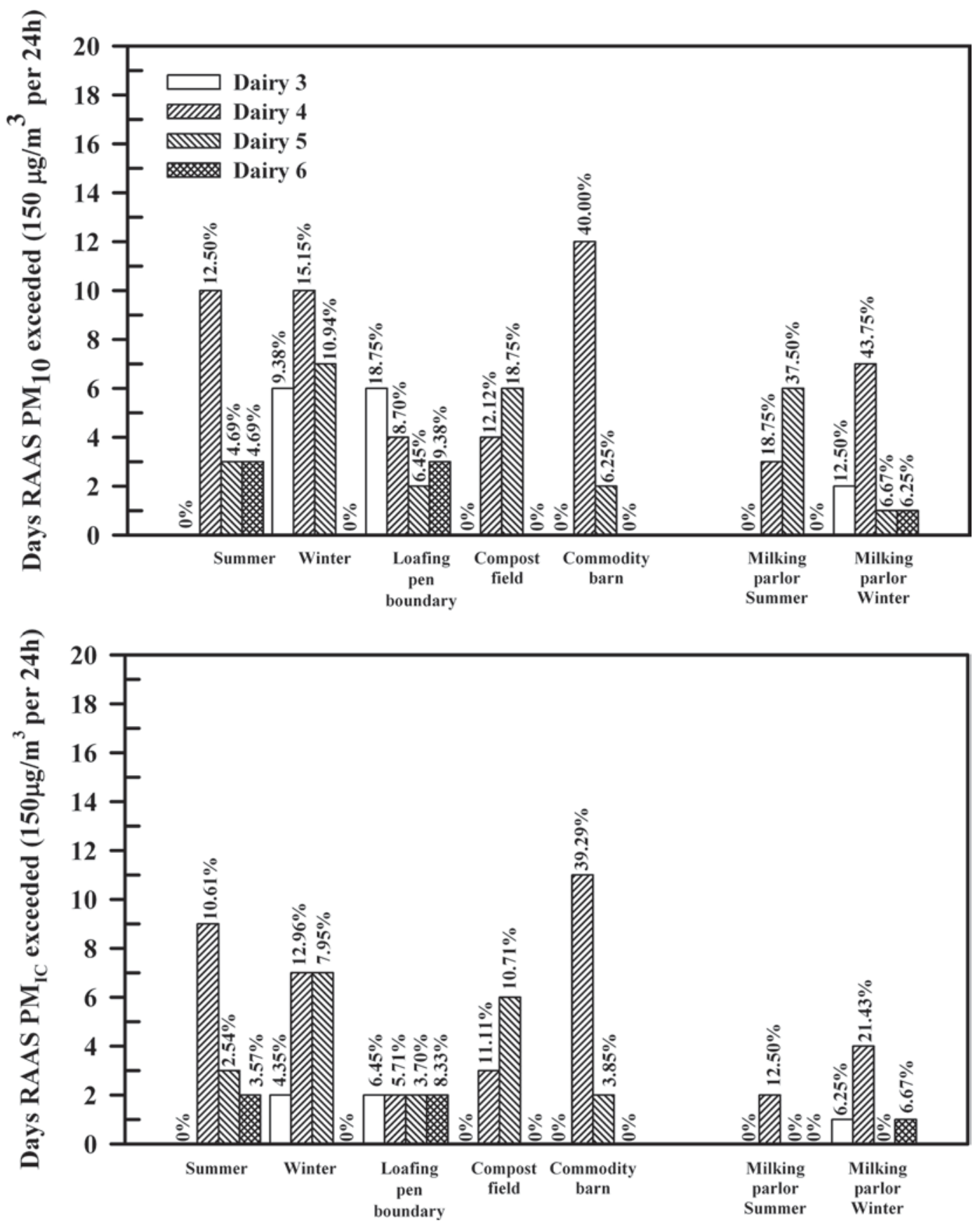

Figure 2. The number of days that reference ambient air samplers (RAAS, 300 series, Andersen Instruments, Smyrna, GA) particulate matter in the size range of $10 \mu \mathrm{m}$ in diameter $\left(\mathrm{PM}_{10}\right)$ and inhalable coarse particulates $\left(\mathrm{PM}_{\mathrm{IC}}\right)$ concentrations exceeded the Environmental Protection Agency's standard $\left(150 \mu \mathrm{g} / \mathrm{m}^{3}\right.$ per $\left.24 \mathrm{~h}\right)$ by dairy for the location sites, summer and winter; includes the milking parlor for which there is no standard for indoor air. The figure above each bar represents the percentage of time out of compliance (days out of compliance/total days monitored).

parlor front and back were compared in the summer and winter (Table 2).

The RAAS mean $\mathrm{PM}_{2.5}$ daily concentrations that exceeded the NAAQS standard $\left(30 \mu \mathrm{g} / \mathrm{m}^{3}\right.$ per $\left.24 \mathrm{~h}\right)$ were determined upwind and downwind for each of the dairy location sites boundary, commodity barn, and compost field in the summer and winter (Figure 3). The mean $\mathrm{PM}_{2.5}$ concentration was determined for inside the milking parlor; however, there is no recognized standard for indoor air. The RAAS mean $\mathrm{PM}_{2.5}$ daily concentrations that exceeded the NAAQS standard of $35 \mu \mathrm{g} / \mathrm{m}^{3}$ per 24 $\mathrm{h}$ were determined by dairy (Figure 3 ). 
Table 2. Reference ambient air samplers 24-h $\mathrm{PM}_{2.5}$ (particulate matter with an aerodynamic diameter of up to $25 \mu \mathrm{m}$ ) aerosol concentrations (mean \pm SEM, minimum, and maximum $\mu \mathrm{g} / \mathrm{m}^{3}$ ) in summer and winter for 4 dairy upwind boundaries, downwind boundaries, commodity barns, compost fields, and milking parlors front and back

\begin{tabular}{|c|c|c|c|c|c|c|c|}
\hline Season & Position & Replications & Probability & Mean & SEM & Minimum & Maximum \\
\hline Winter & Upwind boundary & 30 & 0.3862 & 18.0 & 2.9 & 0.4 & 68.0 \\
\hline Summer & Downwind boundary & 31 & 0.7517 & 17.4 & 2.3 & 5.0 & 68.4 \\
\hline Summer & Commodity barn & 62 & 0.0001 & 12.6 & 0.9 & 1.3 & 39.2 \\
\hline Winter & Commodity barn & 54 & 0.0001 & 21.9 & 2.0 & 21.9 & 109.0 \\
\hline Summer & Compost field & 43 & 0.0022 & 18.1 & 1.9 & 1.7 & 58.8 \\
\hline Summer & Milking parlor back & 36 & 0.0002 & 24.2 & 2.7 & 1.7 & 64.4 \\
\hline Winter & Milking parlor front & 31 & 0.0001 & 63.2 & 9.8 & 11.8 & 205.7 \\
\hline Winter & Milking parlor back & 32 & 0.0002 & 47.6 & 6.3 & 9.6 & 188.0 \\
\hline
\end{tabular}

\section{Analysis of Laser DustTrak PM 10 Mean Particulate Data}

The DustTrak calibration coefficient specific to dairy dust collected was calculated by using 312 RAAS PM PM $_{10}$ $(24 \mathrm{~h})$ concentrations matched with 312 DustTrak $\mathrm{PM}_{10}$ mean (24 hourly) concentrations. The product was determined for each individual paired observation by the following formulas: RAAS $\mathrm{PM}_{10}$ reference concentration/DustTrak $\mathrm{PM}_{10}$ concentration (TSI Inc., 2006). All 312 quotients were averaged to determine the coefficient for dairy dust. The original calibration coefficient was determined by the manufacturer as ISO 12103-1, A1 (formerly called ultrafine Arizona test dust). The coefficient for dairy dust was a 1.94 overestimation compared with the gravimetric-generated data. The following DustTrak data were adjusted using the dairy dust coefficient of 1.94 times the raw data.

The overall DustTrak $\mathrm{PM}_{10}$ mean concentrations for the summer $\left(106.2 \pm 1.9 \mu \mathrm{g} / \mathrm{m}^{3}\right)$ and winter $(108.7$ $\left.\pm 2.2 \mu \mathrm{g} / \mathrm{m}^{3}\right)$ were not different. The DustTrak $\mathrm{PM}_{10}$ mean concentrations for the 4 dairies were different $(P$ $<0.0001$ ). Dairy 6 had the lowest $\mathrm{PM}_{10}$ concentration $\left(71.8 \pm 1.8 \mu \mathrm{g} / \mathrm{m}^{3}\right)$ and $\mathrm{D} 4$ had the highest concentration $\left(148.7 \pm 3.2 \mu \mathrm{g} / \mathrm{m}^{3}\right)$, and the other 2 dairies had similar $(P>0.05)$ concentrations: D3 $(107.4 \pm 3.2 \mu \mathrm{g} /$ $\left.\mathrm{m}^{3}\right)$ and D5 $\left(100.6 \pm 3.2 \mu \mathrm{g} / \mathrm{m}^{3}\right)$. The overall ANOVA DustTrak mean $\mathrm{PM}_{10}$ concentrations were different at 6 dairy site locations: boundary upwind and downwind; commodity barn upwind and downwind; and milking parlor front and back $(P<0.0001)$. The compost field data were calculated separately from the other location data. The $\mathrm{PM}_{10}$ mean concentration values $(P<0.05)$ were similar for upwind $\left(76.6 \pm 2.6 \mu \mathrm{g} / \mathrm{m}^{3}\right)$ and front of the milking parlor $\left(64.9 \pm 2.0 \mu \mathrm{g} / \mathrm{m}^{3}\right)$. The remaining $\mathrm{PM}_{10}$ mean concentrations in decreasing order were different from each other $(P<0.0001)$ : commodity barn $\left(91.1 \pm 1.8 \mu \mathrm{g} / \mathrm{m}^{3}\right)$, downwind $\left(116.4 \pm 3.4 \mu \mathrm{g} / \mathrm{m}^{3}\right)$, and back of the milking parlor $\left(171.0 \pm 4.4 \mu \mathrm{g} / \mathrm{m}^{3}\right)$.
The overall mean $\mathrm{PM}_{10}$ DustTrak concentrations were highest between the hours of 0700 and $0800 \mathrm{~h}$ and lowest between the hours of 1900 and 2000 h; however, the maximum was highest between the hours of 0700 and $0800 \mathrm{~h}$ and the lowest at $0900 \mathrm{~h}$ (Figure 4). The hourly dust concentrations were separated into summer and winter data, but nothing more was revealed by this effort. The summer data were similar to the overall data for the summer and winter combined, and the winter hourly data appeared as 1 group according to the Bonferroni pairwise $t$-test.

The DustTrak $\mathrm{PM}_{10}$ mean concentrations were different $(P<0.0001)$ between the summer and winter and between upwind and downwind for the boundary, commodity barn, compost field, excluding the milking parlor data from the upwind and downwind data (Figure 5). The DustTrak $\mathrm{PM}_{10}$ mean concentration was less in the front $\left(64.9 \pm 2.0 \mu \mathrm{g} / \mathrm{m}^{3}\right.$; maximum, $\left.371.9 \mu \mathrm{g} / \mathrm{m}^{3}\right)$ of the milking parlor compared with the back $(171.0 \pm 4.4$ $\mu \mathrm{g} / \mathrm{m}^{3}$; maximum, $\left.1,302.3 \mu \mathrm{g} / \mathrm{m}^{3} ; P<0.05\right)$.

The overall DustTrak $\mathrm{PM}_{10}$ emission concentration was higher in the summer $\left(96.3 \pm 2.4 \mu \mathrm{g} / \mathrm{m}^{3}\right)$ compared with the winter $\left(64.3 \pm 2.1 \mu \mathrm{g} / \mathrm{m}^{3}\right)$ and the concentration at each location was different $(P<0.05)$. The boundary mean emission was the highest $(91.21 \pm 2.50$ $\mu \mathrm{g} / \mathrm{m}^{3}$; maximum, $1,123 \mu \mathrm{g} / \mathrm{m}^{3}$ ) followed by the commodity barn $\left(80.5 \pm 1.8 \mu \mathrm{g} / \mathrm{m}^{3}\right.$; maximum, $594 \mu \mathrm{g} /$ $\left.\mathrm{m}^{3}\right)$, and then the compost field $\left(67.8 \pm 5.4 \mu \mathrm{g} / \mathrm{m}^{3}\right.$; maximum, 3,692.0). The emission concentration was different for each dairy: D3, $128.9 \pm 4.0 \mu \mathrm{g} / \mathrm{m}^{3}$; D4, $99.4 \pm 4.0 \mu \mathrm{g} / \mathrm{m}^{3} ; \mathrm{D} 5,60.4 \pm 4.0 \mu \mathrm{g} / \mathrm{m}^{3}$; and $\mathrm{D} 6,45.0$ $\pm 1.4 \mu \mathrm{g} / \mathrm{m}^{3}(P<0.05)$.

\section{Comparison of Cyclone Results}

The overall cyclone mean concentrations were larger for winter $\left(43.0 \pm 8.0 \mu \mathrm{g} / \mathrm{m}^{3}\right)$ and downwind $(53.0 \pm$ $\left.8.4 \mu \mathrm{g} / \mathrm{m}^{3}\right)$ compared with summer $\left(29.5 \pm 4.7 \mu \mathrm{g} / \mathrm{m}^{3}\right)$ 

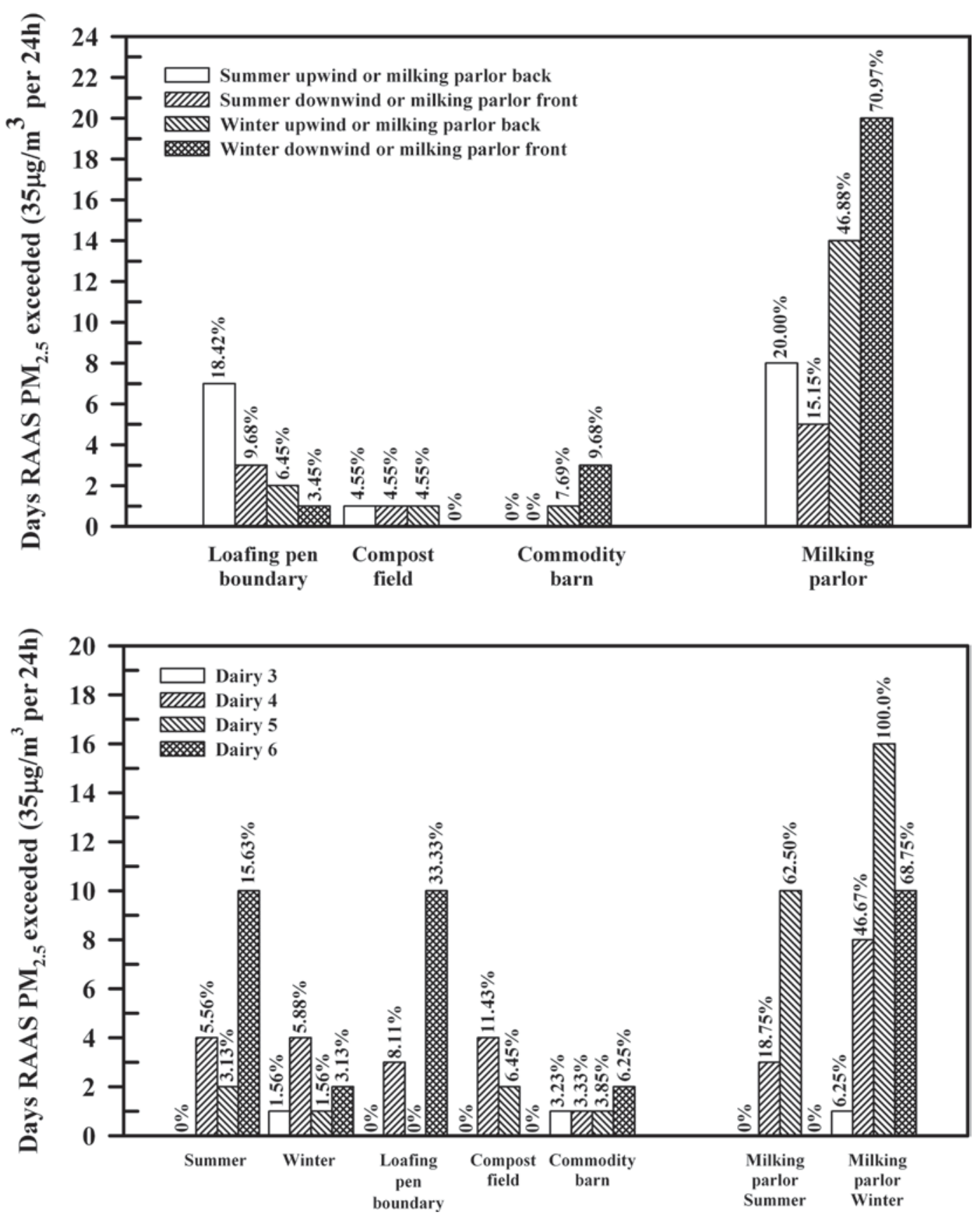

Figure 3. The number of days that reference ambient air samplers (RAAS, 300 series, Andersen Instruments, Smyrna, GA) particulate matter in the size range of $2.5 \mu \mathrm{m}$ in diameter $\left(\mathrm{PM}_{2.5}\right)$ concentrations exceeded the Environmental Protection Agency's standard $\left(35 \mu \mathrm{g} / \mathrm{m}^{3}\right.$ per 24 $\mathrm{h}$ ) by location sites, upwind and downwind in the summer and winter, and by dairies; includes the milking parlor for which there is no standard for indoor air. The figure above each bar represents the percentage time out of compliance (days out of compliance/total days monitored).

and upwind $\left(18.9 \pm 2.8 \mu \mathrm{g} / \mathrm{m}^{3} ; P<0.05\right)$. Stage 1 (5.4$\mu \mathrm{m}$ threshold) of the cyclone collected overall a larger $\left(131.1 \pm 8.0 \mu \mathrm{g} / \mathrm{m}^{3}\right)$ portion of the dust sample than the remaining 4 stages and filter. The remaining stages' collection of dust ranged from $17.7 \mu \mathrm{g} / \mathrm{m}^{3}$ for stage 2 to $13.8 \mu \mathrm{g} / \mathrm{m}^{3}$ for the filter $(P<0.05)$. There were no significant differences among location sites (boundaries, $36.8 \pm 7.7 \mu \mathrm{g} / \mathrm{m}^{3}$; commodity barns, $40.2 \pm 8.6 \mu \mathrm{g} /$ $\mathrm{m}^{3}$; and compost fields, $27.8 \pm 5.0 \mu \mathrm{g} / \mathrm{m}^{3}$ ) or among dairies: D3, $43.9 \pm 14.4 \mu \mathrm{g} / \mathrm{m}^{3}$; D4, $33.8 \pm 7.8 \mu \mathrm{g} / \mathrm{m}^{3}$; $\mathrm{D} 5,35.7 \pm 8.3 \mu \mathrm{g} / \mathrm{m}^{3}$; and D6, $32.3 \pm 7.1 \mu \mathrm{g} / \mathrm{m}^{3}$.

\section{Summary of Summer and Winter Weather Station Data}

The mean $( \pm$ SEM $)$, maximum, and minimum weather measures are presented in Table 3 . 


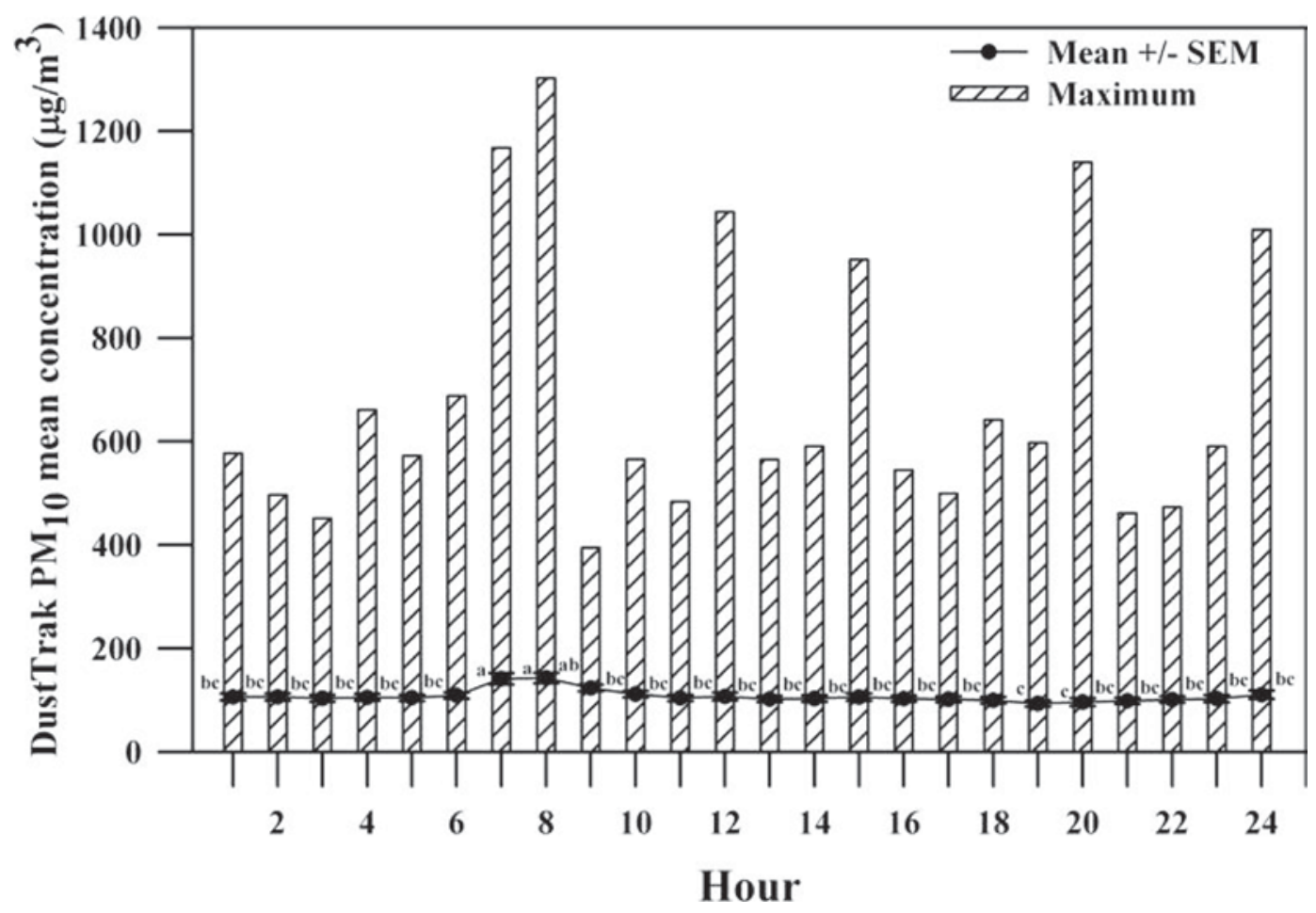

Figure 4. DustTrak (TSI Inc., Shoreview, MN) particulate matter in the size range of $10 \mu \mathrm{m}$ in diameter $\left(\mathrm{PM}_{10}, \mathrm{mean}_{ \pm} \mathrm{SEM}\right)$ and maximum dust concentration $\left(\mu \mathrm{g} / \mathrm{m}^{3}\right)$ by hour for 4 dairies (average of summer and winter data combined). A minimum of 216 repeated observations were averaged for each hour. The Bonferroni pairwise $t$-test $(P<0.05)$ divided the hours (means) into 2 distinct groups (lowercase letters).

\section{DISCUSSION}

The RAAS-300 collectors indicated that dairy $\mathrm{PM}_{10}$ concentrations were higher $\left(97.9 \pm 4.4 \mu \mathrm{g} / \mathrm{m}^{3}\right)$ in the winter compared with the summer $\left(71.9 \pm 4.4 \mu \mathrm{g} / \mathrm{m}^{3}\right)$. However, the DustTrak collectors indicated no significant difference between summer $\left(106.2 \pm 1.9 \mu \mathrm{g} / \mathrm{m}^{3}\right)$ and winter $\left(108.7 \pm 2.2 \mu \mathrm{g} / \mathrm{m}^{3}\right)$. In contrast, feed yard RAAS $\mathrm{PM}_{10}$ concentrations were higher in the summer $\left(261.8 \pm 34.3 \mu \mathrm{g} / \mathrm{m}^{3}\right)$ compared with the winter $(97.7$ $\pm 12.9 \mu \mathrm{g} / \mathrm{m}^{3}$; Purdy et al., 2007). Three obvious factors probably account for some of the contrast between dairies and feed yards. First, the feed yards had 50,000 to 100,000 more active, young animals than the dairies $(2,400$ to 7,100 cows $)$. Second, there are distinct behavioral differences between feeder calves and cows (Mitlohner et al., 2001). Third, the feed yards were on a clay-type soil, whereas the dairies were on extremely sandy soil.

The dairy RAAS $\mathrm{PM}_{2.5}$ concentrations were significantly higher in the summer $\left(29.5 \pm 2.3 \mu \mathrm{g} / \mathrm{m}^{3}\right)$ compared with the winter $\left(18.1 \pm 1.1 \mu \mathrm{g} / \mathrm{m}^{3}\right)$. In feed yards, the $\mathrm{PM}_{2.5}$ concentrations were similar and they too were significantly higher in the summer $(26.4 \pm 3.1$ $\left.\mu \mathrm{g} / \mathrm{m}^{3}\right)$ compared with the winter $\left(12.8 \pm 1.1 \mu \mathrm{g} / \mathrm{m}^{3}\right.$; Purdy et al., 2007).
The number of days that the RAAS $\mathrm{PM}_{10}$ and $\mathrm{PM}_{2.5}$ concentrations exceeded the NAAQS concentration standards for $24 \mathrm{~h}$ is extremely important to the dairies, as they could be fined for exceeding these standards. For example, the RAAS $\mathrm{PM}_{2.5}$ concentration for D6 was out of compliance for $10 \mathrm{~d}$ at the boundary and for $2 \mathrm{~d}$ at the commodity barn. The $\mathrm{PM}_{10}$ concentration for D5 was out of compliance for $12 \mathrm{~d}$ at the commodity barn, $4 \mathrm{~d}$ at the compost field, and $4 \mathrm{~d}$ at the boundary. The $\mathrm{PM}_{\mathrm{IC}}$, based on the latest definition, can be calculated by subtracting $\mathrm{PM}_{2.5}$ from the $\mathrm{PM}_{10}$ concentration, which might be an advantage to the dairy. Still, the $\mathrm{PM}_{\mathrm{IC}}$ of $\mathrm{D} 6$ was out of compliance for $2 \mathrm{~d}$ at the boundary, and that of D5 was out of compliance for 11 $\mathrm{d}$ at the commodity barn, $3 \mathrm{~d}$ at the compost field, and $2 \mathrm{~d}$ at the boundary. Collectively, the dairies were not compliant for $\mathrm{PM}_{10}$ particulates on 39 of $495 \mathrm{~d}$ worked (7.9\%) and not compliant for $\mathrm{PM}_{2.5}$ particulates on 24 of $439 \mathrm{~d}$ worked (5.5\%).

Downwind particulate concentrations are expected to be higher than upwind concentrations when wind sweeps over a dairy or feed yard. Nevertheless, the $\mathrm{PM}_{2.5}$ dust collected at the upwind boundary locations during the summer was out of compliance for $7 \mathrm{~d}$ and the $\mathrm{PM}_{10}$ dust collected at the summer upwind boundary site was out of compliance for $1 \mathrm{~d}$. This excessive 

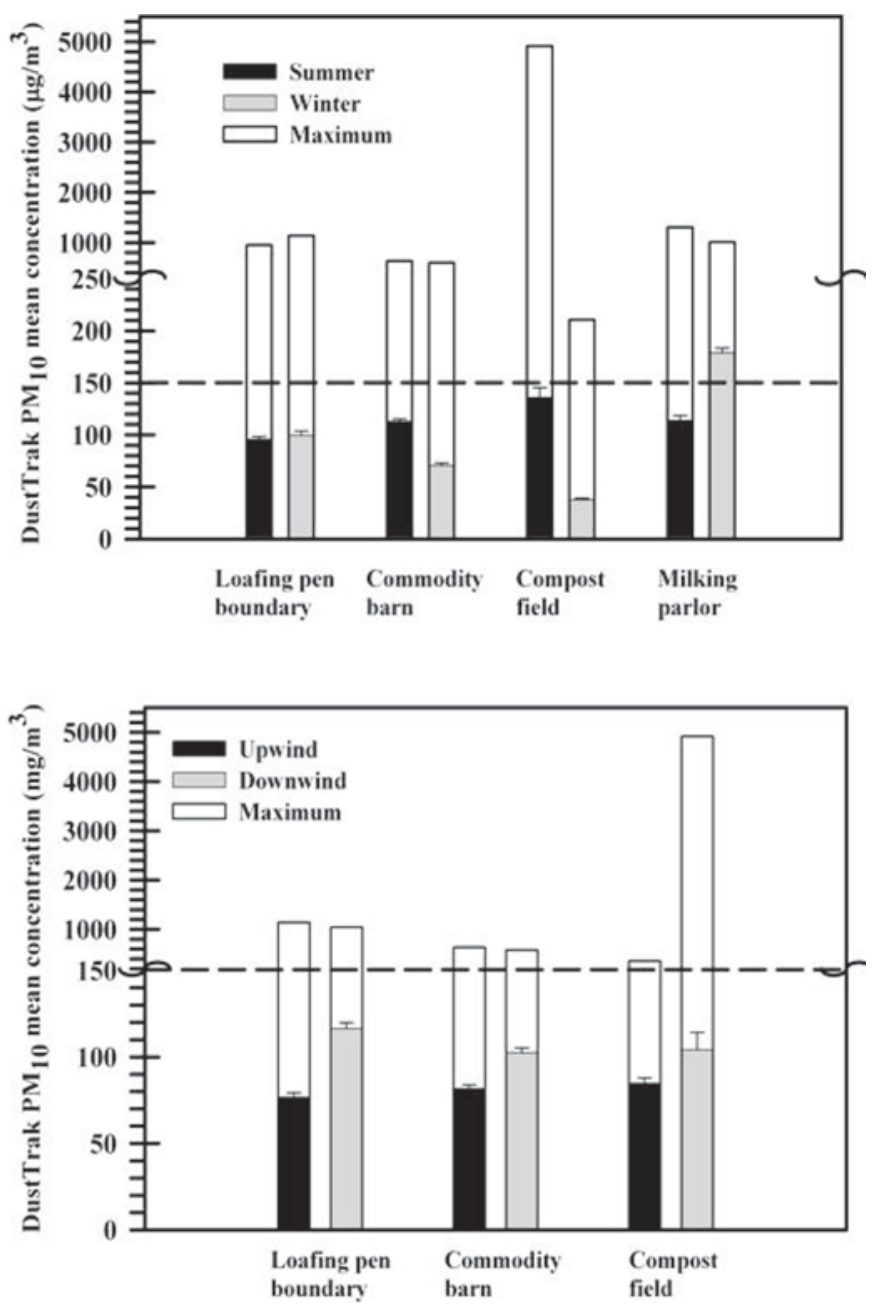

Figure 5. DustTrak (TSI Inc., Shoreview, MN) particulate matter in the size range of $10 \mu \mathrm{m}$ in diameter $\left(\mathrm{PM}_{10}\right.$, mean \pm SEM $)$ and maximum concentration $\left(\mu \mathrm{g} / \mathrm{m}^{3}\right)$ summer and winter (average of upwind and downwind data combined) and upwind and downwind (average of summer and winter data combined). Number of hourly observations per bar for summer and winter ranged from 652 to 1,126 , and observations per bar for upwind and downwind ranged from 879 to 1,061 .

$\mathrm{PM}_{2.5}$ dust upwind may have originated from nearby gravel roads, a distant dairy, or another distant source such as industrial activities or automotive emissions.

The mean dairy RAAS $\mathrm{PM}_{10}$ and $\mathrm{PM}_{\mathrm{IC}}$ model statements for emissions were not significant. The reason for this unfortunate model statement was that some equipment failure occurred at both the upwind and downwind boundary sites. Thus, sufficient numbers of $\mathrm{PM}_{10}$ 24-h upwind concentrations could not be matched with downwind concentrations for a good model statement. The mean RAAS $\mathrm{PM}_{2.5}$ concentrations were lower in the winter $\left(9.2 \pm 1.9 \mu \mathrm{g} / \mathrm{m}^{3}\right)$ compared with the summer $\left(15.2 \pm 3.6 \mu \mathrm{g} / \mathrm{m}^{3}\right)$. Dairy 6 had a higher $(26.8 \pm$ $7.0 \mu \mathrm{g} / \mathrm{m}^{3}$ ) mean $\mathrm{PM}_{2.5}$ emission compared with the other 3 dairies. Dairy 6 was the oldest dairy and its cow numbers $(2,400)$ were the lowest. Therefore, it appears that the cow numbers were less important than other dust-creating factors. The DustTrak provided a minimum of 216 hourly matched upwind and downwind $\mathrm{PM}_{10}$ concentrations. The $\mathrm{PM}_{10}$ emission concentrations were different for each of the dairies, each of the location sites, and for the seasons.

It should be noted that all dust collected by the instruments, no matter its origin, was included in the calculations. The road dust was a large contributing source of dust considering the frequent traffic that occurred in and around large dairies or feed yards. Almost all dairies and feed yards had unpaved internal roads and many dairies were located some distance from macadam or concrete access roads. The traffic originated internally with routine feed trucks, people in trucks looking for and caring for sick or injured cows, vehicles carrying individuals responsible for checking cows for pregnancy, individuals who sort cows that are about to give birth, and vehicles with workers arriving for or departing from their work shift. External traffic occurred when milk tanker semi-trailer trucks arrive to pick up the milk and departed hauling the milk, salespersons bringing supplies and exiting the dairy, veterinarians under contract, and semi-trailer trucks hauling feed and minerals to the commodity barn and then exiting the property.

Certainly, dairy dust frequently exceeded the NAAQS ambient air 24-h standards for both $\mathrm{PM}_{10}$ and $\mathrm{PM}_{2.5}$ concentrations in both winter and summer, upwind and downwind at the boundary, commodity barn, and compost field. DustTrak maximum hourly concentrations show the same pattern in summer and winter. Nonetheless, feed yard RAAS $\mathrm{PM}_{10}$ concentration was 3.64-fold higher than that in the dairy in summer and 1.36-fold higher in the winter. The feed yard RAAS $\mathrm{PM}_{2.5}$ concentration was $15.0 \mu \mathrm{g} / \mathrm{m}^{3}$ in the winter and $27.7 \mu \mathrm{g} / \mathrm{m}^{3}$ in the summer compared with dairy $\mathrm{PM}_{2.5}$ in the winter $\left(32.6 \mathrm{~g} / \mathrm{m}^{3}\right)$ and summer $\left(18.1 \mathrm{~g} / \mathrm{m}^{3}\right.$; Purdy et al., 2007). The dairy results indicated that outside workers needed to protect themselves from dust particulates, particularly on windy days and especially during wind peak hours (0700 through $0800 \mathrm{~h}$ with properly fitted N95 respirator masks (95\% efficiency against particulate aerosols free of oil). Dairies could minimize a certain amount of dust by surfacing the gravel roads with macadam, thus eliminating most of the dust caused by vehicular traffic. Curtailing dust in the dairy loafing pen in a semiarid climate is difficult at best, as precious water only settles the dust for a short time.

Interest in the toxicity of agricultural dust particles is relatively new, especially interest in the size and chemistry of the particles as related to human and animal 
Table 3. Weather station parameters (mean \pm SEM, maximum, and minimum) collected from 4 dairies in the southern High Plains of New Mexico

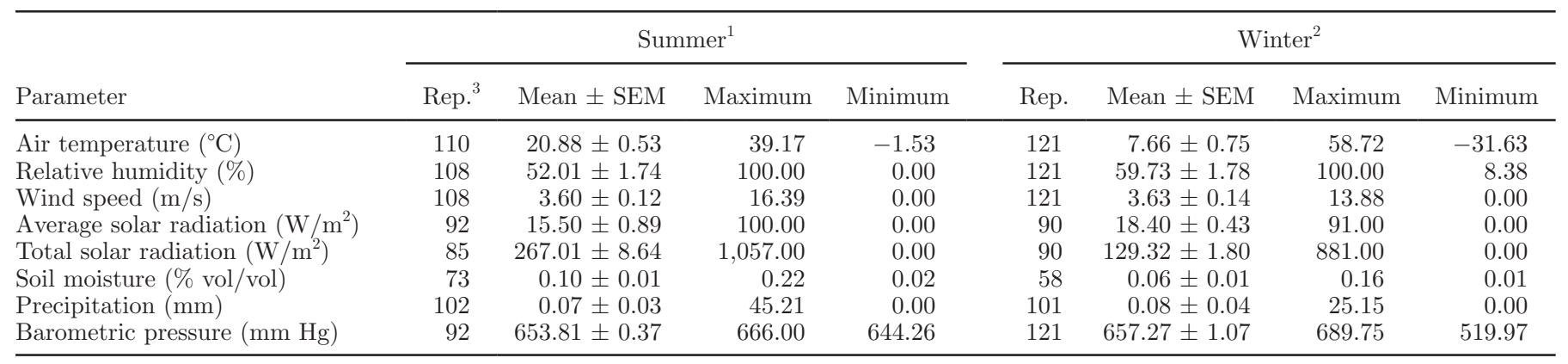

${ }^{1}$ Summer was defined as April through September.

${ }^{2}$ Winter was defined as October through March.

${ }^{3}$ Rep. $=$ replication.

illness. It appears that the common denominator of CAFO dust is endotoxin found in both $10-$ and $2.5-\mu \mathrm{m}$ particles, which trigger local and systemic inflammatory reactions upon inhalation (Purdy et al., 2004b). The smaller particles can be inspired deep into the lung alveoli and affect the immune system (Purdy et al., 2008). In addition to endotoxin, allergens, microbial pathogens, bacterial toxins, fungal spores, and mycotoxins can be attached to dust particles that, when inhaled, can cause dramatic local and systemic inflammatory reactions or, in some cases, infections.

The milking parlor indoor air $\mathrm{PM}_{10}$ and $\mathrm{PM}_{2.5}$ concentrations were expected to be higher than those of the ambient air. It was surprising that the $\mathrm{PM}_{2.5}$ concentration exceeded $>35 \mu \mathrm{g} / \mathrm{m}^{3}$ for $49(40 \%)$ out of $123 \mathrm{~d}$ worked compared with the $\mathrm{PM}_{10}$ concentration, which exceeded $150 \mu \mathrm{g} / \mathrm{m}^{3}$ for $20(15 \%)$ out of $135 \mathrm{~d}$ worked. The $\mathrm{PM}_{2.5}$ concentration of the milking parlor in the summer exceeded $35 \mu \mathrm{g} / \mathrm{m}^{3}$ for $15 \mathrm{~d}$ and for $36 \mathrm{~d}$ in the winter. The greater number of days out of compliance in the winter was attributed to less ventilation (Olesen, 2004) and to the soot emitted by heaters. Indoor guidelines and standards for other measures such as ventilation rates, common indoor contaminants, organic compounds, and labeling schemes for low-volatile organic chemicals do exist (National Research Council Canada, 2005). The higher concentrations in winter were caused by the antiquated natural gas heaters used to keep the workers warm in the milking parlors. These heaters produced carbon, which was very noticeable on the outside of the heaters, and the carbon was emitted into the air and deposited on the RAAS 24-h gravimetric filters, turning them solid black. These heaters should be replaced with low-carbon-emissions heaters or electric heaters. If the heaters are not replaced, then the milking parlor workers should wear N95 respirator masks during their work shift while the heaters are in service during the winter. The workers on each of the 3 shifts are exposed to a high soot concentration, high humidity, and lower ventilation rates for $8 \mathrm{~h}$ (Kovesi et al., 2007). The soot and reduced ventilation may have a negative effect on milk production, although the cows are only exposed 3 times daily for a short time compared with the human exposure.

All CAFO produce aerosols, bioaerosols, and odor pollution that may affect the air quality and water quality of the surrounding environment (Purdy et al., 2004b). The largest part of this pollution (18 million tonnes/year) is generated by the excrement of animals. Most facilities have a large amount of road dust created by vehicular traffic on gravel and unpaved roads. Public health organizations, the public, veterinarians, CAFO industries, and federal and state regulators want to make sure that this pollution does not adversely affect the health of occupation workers, surrounding residents, or animals contained in the CAFO. They want to ensure that the surrounding environment, which includes the air and water reservoirs on the surface and underground, is not adversely affected. The EPA has promulgated air and water quality standards to safeguard the health of humans.

The two air quality particulate standards (for $\mathrm{PM}_{10}$ and $\mathrm{PM}_{2.5}$ ) were determined mainly from the urban pollution experience involving diesel and gasoline engine exhaust, and coal and petroleum exhaust from residential heating facilities and industrial facilities. How these air quality standards might affect the future of unknown $\mathrm{PM}_{10}$ and $\mathrm{PM}_{2.5}$ concentrations of agricultural and CAFO dust is not readily known. There is a paucity of data concerning dust concentrations in rural areas (Bunton et al., 2007). This is evident when the instruments used in monitoring aerosols were exclusively made for measuring urban aerosol pollution, not for CAFO ambient aerosols heavily laden with particulates 
(Purdy et al., 2007). It is not known if CAFO rural $\mathrm{PM}_{10}$ and $\mathrm{PM}_{2.5}$ dust is as toxic as the same amount and size of urban dust particles.

In conclusion, our hypothesis was correct. Collectively, the 4 dairies were out of compliance for $\mathrm{PM}_{10}$ concentrations for $39 \mathrm{~d}$ ( $7.9 \%$ of the time studied) and for $\mathrm{PM}_{2.5}$ concentrations for $24 \mathrm{~d}(5.5 \%)$. Dairies could decrease the concentration of dust they produce by slowing vehicular traffic on the premises. Road dust could be almost entirely eliminated by paving gravel roads with macadam. Dairies could improve the air quality of their milking parlors in winter by replacing gas heaters with electric heaters. All outside workers should wear N95 dust masks on dusty days; these masks should fit properly and be mandatory for all workers in the commodity barn and those who work the compost fields.

\section{REFERENCES}

Bunton, B., P. O. Shaughauessy, S. Fitzsimmons, J. Gering, S. Hoff, M. Lyngbye, P. S. Thorne, J. Wasson, and M. Werner. 2007. Monitoring and modeling of emissions from concentrated animal feeding operations: Overview of methods. Environ. Health Perspect. 115:303-307.

Centner, T. J. 2001. Evolving policies to regulate pollution from animal feeding operations. Environ. Manage. 28:599-609.

Centner, T. J. 2003. Regulating concentrated animal feeding operations to enhance the environment. Environ. Sci. Policy 6:433-440.

Cleland, W. L. 1998. Air Pollution Regulation. Pages 11.3-11.13 in Air Quality Control Handbook. E. R. Alley and Associates, McGrawHill Publishers, New York, NY.

Code of Federal Regulations. 1997a. 40 CFR, Part 75: Continuous Emission Monitoring; Appendix K.

Code of Federal Regulations. 1997b. 40 CFR, Part 75: Continuous Emission Monitoring; Appendix L.

Environmental Protection Agency. 2006. EPA PM Standards Revision. http://www.epa.gov/pm/naaqsrev2006.html Accessed Feb. 29, 2008.

Green, M., and J. Xu. 2007. Causes of haze in the Columbia River Gorge. J. Air Waste Manag. Assoc. 57:947-958.

Kirkhorn, S. R. 2002. Community and environmental health effects of concentrated animal feeding operations. Minn. Med. 85:38-43.

Kovesi, T., N. L. Gilbert, C. Stocco, D. Fugler, R. E. Dales, M. Guary, and D. Miller. 2007. Indoor air quality and the risk of lower respiratory tract infections in young Canadian Inuit children. CMAJ 177:155-160.

Liu, L. J. S., J. C. Slaughter, and T. V. Laron. 2002. Comparison of light scattering devices and impactors for particulate measurements in indoor, outdoor, and personal environments. Environ. Sci. Technol. 26:2977-2986.

Logan, W. P. 1953. Mortality in the London fog incident (1952). Lancet 1:336-338.

Mitlohner, F. M., J. L. Morrow-Tesch, S. C. Wilson, J. W. Dailey, and J. J. McGlone. 2001. Behavioral sampling techniques for feedlot cattle. J. Anim. Sci. 79:1189-1193.

National Research Council Canada. 2005. Indoor air quality guidelines and standards. R R - 204, Final Report 5.1 - CMEIAQ-II. Consortium for Material Emission and IAQ Modeling II:1-44.

Olesen, B. W. 2004. International standards for the indoor environment. Indoor Air 14(Suppl 7):18-26.

Purdy, C. W., R. N. Clark, and D. C. Straus. 2007. Analysis of aerosolized particulates of feedyards located in the Southern High Plains of Texas. Aerosol Sci. Technol. 41:1-13.

Purdy, C. W.. R. C. Layton, D. C. Straus, and J. R. Ayers. 2008. Effects of inhaled fine dust on lung tissue changes and antibody response induced by spores of opportunistic fungi in goats. Am. J. Vet. Res. 69:501-511.

Purdy, C. W., D. C. Straus, N. Chirase, D. B. Parker, J. R. Ayers, and M. D. Hoover. 2002a. Effects of aerosolized endotoxin in feedyard dust on weanling goats. Small Rumin. Res. 46:133-147.

Purdy, C. W., D. C. Straus, and R. N. Clark. 2004a. Diversity of Salmonella serovars in feedyard and nonfeedyard playas of the Southern High Plains in the summer and winter. Am. J. Vet. Res. 65:40-44.

Purdy, C. W., D. C. Straus, D. B. Parker, J. R. Ayers, and M. D. Hoover. 2002b. Treatment of feedyard dust containing endotoxin and its effect on weanling goats. Small Rumin. Res. 46:123-132.

Purdy, C. W., D. C. Straus, D. B. Parker, B. P. Williams, and R. N. Clark. 2001. Water quality in cattle feedyard playas in winter and summer. Am. J. Vet. Res. 62:1402-1407.

Purdy, C. W., D. C. Straus, D. B. Parker, S. C. Wilson, and R. N. Clark. 2004b. Comparison of the type and number of microorganisms and concentration of endotoxin in the air of feedyards in the Southern High Plains. Am. J. Vet. Res. 65:45-52.

Samet, J. M., F. Dominici, F. C. Curriero, I. Coursac, and S. L. Zeger 2000. Fine particulate air pollution and mortality in 20 US cities, 1987-1994. N. Engl. J. Med. 343:1742-1749.

SAS Institute. 1988. SAS User's Guide: Version 6.03 Edition. SAS Inst., Inc., Cary, NC.

Seinfeld, J. H. 2004. Air pollution: A half century of progress. AIChE J. 50:1096-1108.

T. S. I. Inc. 2006. DustTrak Aerosol Operation and Service Manual. TSI Incorporated, Shoreview, MN. 